\title{
Professionalization of The Principal's Role
}

\author{
Tihana Kokanović ${ }^{*}$ (D), Siniša Opić ${ }^{2}$ (D) \\ ${ }^{1}$ Kindergarten Sisak Stari, Sisak, Croatia, e-mail: kokanovictihana@gmail.com \\ ${ }^{2}$ Faculty of Teacher Education, University of Zagreb, Zagreb, Croatia, e-mail: sinisa.opic@ufzg.unizg.hr
}

\begin{abstract}
The aim of this work is to point out the importance of the professionalization of the principal's role in education institutions, with an accent on preschool institutions. The sample included principals $(\mathrm{N}=57)$ of preschool institutions in Central Croatia. The goal was to test the mediation relationship through SEM and examine the direct influence of interpersonal relationships within the preschool institution on the development of its work quality; furthermore, to test the indirect influence of these relationships by introducing the mediation variable of professional competence. The structured modelling in the AMOS was applied for testing the direct and indirect influence. The contribution of interpersonal relationships on the work quality is high and statistically significant $(\beta=0,920)$, which confirms the direct influence. For testing the mediation effects, a bootstrapping method was designed that confirmed the indirect influence of interpersonal relationships on the work quality with the statistically significant serial mediator of professional competence $(p=0,016)$, thereby confirming partial mediation. This research determined that positive interpersonal relations, mediated by the principal's professional competence, have a positive effect on the work quality of a preschool institution. In order for preschool institutions to reach the desired quality, it is necessary for them to be managed by professionally empowered and expert principals who promote prime cooperative relationships as the starting point in developing a high-quality institution. The results of this research contribute to a clearer perception and understanding of the professionalization of the principal's role through key areas of his/her work and activity, and the possibility of their practical implementation into education institutions.
\end{abstract}

Keywords: professionalization, principals, preschool institutions, professional competences, structural modelling.

\section{Introduction}

The role of the principal is key in the process of development and work quality of the preschool institution and its stakeholders. In order for a preschool institution to successfully thrive and realise its developmental potential, the principal's competences are of crucial importance because only expert and competent principal, together with his/her co-workers, has the possibility to realise the basic tasks in the field of early and preschool education (Kokanović, 2021). Since early development and learning of children is considered particularly significant for the development of a stable personality, it is key that the first institution children are involved in is directed toward high-quality work improvement. This research indicates the need for the professionalization of the principal's role in Croatia and aims to contribute to understanding and determining the professional role and function of the principal in realizing high-quality preschool institutions. Numerous European documents that prescribe the guidelines for national educational policies (European Council, 2009) point to the significance of quality leadership of education institutions. Moreover, OECD (2005) and ETUCE (2008) prescribe competences needed for the organisational component of the institution, which imply the skills for developing positive cooperation and partnerships, teamwork, and successful management and leadership of the institution itself. The documents accentuate skills of deliberation and self-reflection, assuming responsibility for one's own professional development and of other participants, and the competences required for creating educational policies and introducing innovation in the educational practice. In order to set a clear competence frame necessary for successful management of a preschool institution, regulating the principal's role from a function into a profession is required. As recommendations for the principals' professionalization, Hallinger and Snidvongs (2005, acc. to Staničić, 2006) single out the following key criterions to be fulfilled: fundamental knowledge and skills, continuous lifelong learning and ensuring permanent support in the course of heading educational institutions. The professionalization requires continuous lifelong learning in order for the principals to keep Corresponding author: kokanovictihana@gmail.com 
up with the contemporary insight into the work and efficiently manage preschool institutions. Croatia is one of the rare countries without a regulated system of education and professional training for principals, so those who are not ready or qualified take on this role and are in most cases left to their own devices and/or opportunities for professional development. According to many authors, successful management of educational institutions guarantees positive development of the overall process, therein the education system (Caldwell, 2005; Rood, 2006; Leithwood and Day, 2007; Hersey, Blanchard and Johnsonet, 2008; Grint and Holt, 2011; Fullan, 2011; Earley and Greany, 2017). Therefore, the professionalization of principals should become an imperative to all the countries aiming to establish quality in this part of the system. The standards of the occupation, qualifications and licencing should be a point of departure for the professionalization of the principal's role through educational policies. In 2016, the Ministry of Science and Education of the Republic of Croatia has made public the conceptualised relevant documents, devised by an expert work group, that define the criterions and guidelines for the professionalization of preschool institutions' principals. However, apart from the conceptualisation, further development in this regard did not happen. The education standards are key to the professionalization because they define the qualifications and competences required of principals before taking on this role. The standards unambiguously delineate knowledge, abilities, skills and values principals should have (or master) in order to assume this role. Besides, they provide an opportunity to choose proficient experts needed for developing high-quality education institutions.

\section{Professional competences of the principal}

The role of the principal is multifold and encompassed by the interdisciplinary area, so it is expected that the principal possesses a wide spectrum of knowledge and skills in order to perform this role successfully. In the document Strategy of education, science and technology (2014), the intention is visible of instating the systematic evaluation of the work of principals, which would also mean securing the adequate education or advancement in order for the principals to be prepared even before assuming this role. Furthermore, systematic evaluation of the principal's work should accordingly be preceded by defining the standards of the occupation and respective qualifications as well as licencing, which is the case in many countries (England, USA, New Zealand, Australia, etc.), but not in Croatia. Bearing in mind the guidelines from Council Recommendation on Key Competences for Lifelong Learning (2018), it is a duty and obligation of every state to secure all the conditions and resources for quality education, wherein the opportunity for the inclusion of education workers in various forms of professional training so they can continuously excel their professional competences. The principal's role is complex and, as stated by the European Commission (2012, acc. to Kokanović, 2021), its influence on defining and determining the quality of an education institution is the most prominent; therefore, it is necessary to dedicate great attention to the professionalization of this role. Isto singles out some areas in which the principals participate every day as key for developing quality preschool institutions, from designing the joint vision and mission, shaping the curricula and educational process, securing all the conditions for the realisation of the process, to developing partner relations and professional growth of all participants (ibid, 2021). It is particularly significant that the principal is able to provide support, motivate cooperative relations within the institution, create a learning community together with the co-workers based on trust and mutual respect, generate new insight and knowledge and incorporate them in the educational practice itself. The principals are responsible for and obliged to assume the leading role in creating the learning community by designing and securing the conditions and resources for the professional training and learning of all participants in the institutions they head (Matsumura, Garnier and Resnick. 2010; Snyder et al. 2011). It is expected of the principal to be skifful and able to assess the wide spectrum of characteristics contributing to promoting quality practice, so it is unquestionable that this person must be professionally aware and competent for responding to all the challenges encountered in everyday work. It ensues from the aforementioned that educational policies of each state are obliged to provide the conditions for developing and empowering the professional competences upon the completion of initial education, starting from defining the standards and programmes that will secure systematic and continuous lifelong learning. In order for the principals to ensure all these conditions and create opportunities for learning and development within their institutions, it is key that they themselves are professionally competent in all areas of their activity and work. Hence, there is no doubt that the professionalization of her/his role is an exceptionally significant process that should become the priority activity for the designers of educational policy of each state that strives for a quality education system. The fact that Croatia does not have a defined nor systematic education standard for principals is a worrying piece of information that places principals and education institutions in a bad position where quality and continuous advancement can hardly be expected. 


\section{The quality of the preschool institution's work}

The quality of preschool institutions is determined by various factors. Cultural determination of the quality may assume the leading position in defining the concept itself. Having in mind the fact that a person's identity encompasses values, beliefs, experiences, knowledge and action, it can be said that the social context in which a person exists is formed on those principals. The quality perceived in a surrounding and social context does not necessarily need to entail the same characteristics in some other context, nor be equally perceived. Preschool institutions are expected to achieve the consensus of certain factors in the education system in order to realise the planned outcomes of joint educational activity. When we speak of the preschool institution's quality, it is a given (or should be) that it is not static nor constant, but a developmental component that requires systematic and continuous work to promote its sustainability. The fundamental starting point for developing quality preschool institutions should have its stronghold in understanding and perceiving the child, for whom the environment is created in the first place. If a child is perceived as a competent, active, reflexive, curious and intelligent being, the provision of quality education will become our imperative and guide in creating and developing as quality preschool institutions as possible. By considering scientific insight about learning and development, numerous authors (Sekulić-Majurec, 1997; Gopnik et al., 2003; Mlinarević, 2004; Rinaldi, 2006; Dahlberg and Moss, 2006; Miljak, 2009; Jurčević-Lozančić, 2011; Slunjski, 2006; 2008; 2011; 2018) suggest the direction in forming quality, incentive environment in order for the child to develop his/her potentials. Hence, the role of a high-quality preschool institution in the child's development is indisputable. The contemporary view on the child as an active and competent participant and (co)creator of the education process requires a surrounding and conditions for nourishing all his/her potentials. The inclusion in early and preschool education positively affects and brings advantages not only to an individual but also to the overall society (Vandenbroeck et al, 2017) with regard to better educational achievement, the results on the labour market and overall more connected and inclusive societies. Furthermore, the inclusion in the quality early and preschool system is considered a key factor in decreasing the dropout rate (European Cosmission, 2014), and only high-quality inclusive services which are not costly bring welfare to individuals, while lowquality systems have a negative effect on the development of children and societies as a whole (Melhuish et all., 2015). Crucial bearers of changes and improvement of the institution's work quality are foremost its participants who can detect the strong and weak suits in their everyday work, whereby they contribute to the planned and systematic improvement. The development of a learning community should be initiated by continuous reflection, discussion and joint (co)operation of all its stakeholders.

\section{Cooperative relationships within the preschool institution}

The quality of life in a preschool institution greatly depends on interpersonal relationships of all employees. Peterson (2002) states with a metaphoric expression that if an institution is to be nourished with heart, soul and spirit, as children deserve, then it is necessary to invest constantly in all the segments leading to this goal. Once achieved, the quality within the institution needs to be cultivated and empowered in order to develop the institution according to the set goals. Quality relationships, successfully realised cooperation and teamwork are the elements that reflect a well-developed culture of an institution. Vujičic (2011) emphasises that the institution's culture is reflected in interpersonal relationships of all participants, their joint work, institution's management, organisational and physical surrounding and professional development of its workers through exploration of one's own education practice with the goal of its improvement. In such a way, an institution has a powerful leverage for starting self-organising processes, i.e. the ability and opportunity to change and develop. The principal is key in developing cooperative culture and quality human relationships in the institution. If he/she shows care and understanding for all the participants, encourages forming the vision, promotes and lives the aspiring values, there is a great possibility that other relevant actors will do the same. Fullan (1993) stresses the importance of collegial relationships inside the institutions because they are the basis for promoting successful social interactions amongstall participants. It is important to emphasise that thriving cooperative relations need to be developed among all participants in the education process, within the institution as well as with external factors. A preschool institution striving toward developing a learning community provides the child with a sense of belonging, positively affects all the aspects of his/her development, and with that a feeling of togetherness and acceptance is created in the long run. The children who grow up in supporting communities ruled by an atmosphere of cooperative culture, warm and caring relationships and mutual respect and appreciation will themselves feel they can contribute to its functioning and development. In such a way, children will learn experientially about democratic values directly from their environment, which will exude a significant positive effect on their overall development. Therein, institutions that promote such values indisputably develop their own quality. Quality cooperative relationships contribute to empowering team work, joint 
reflection and analysing one's own practice, thereby personal and professional growth and development of all participants. Quality cooperative relationships are the foundation for excelling the quality of the institution itself. Slunjski (2008) states the need to create an atmosphere that would motivate collective inquiry, preceded by mutual trust and respect of all participants (preschool teachers, expert associates, principals and other employees). In order for the dialogue culture to thrive, all stakeholders foremost need to be in an equal position, have the liberty and autonomy in making decisions, a pronounced sense of responsibility and belonging because in such a way the collective identity will be enforced, leading to the improvement of quality cooperative relationships. We can conclude from the aforementioned that the role of the principal is crucial in this segment too because, if he/she has a goal of establishing such relationships within the institution and strives toward appreciative, equal communication, then the results will follow. Therefore, professional competences of the principal as the institution's leader and realised quality cooperative relationships are the point of departure for promoting preschool institution's work quality; hence, the focus of this research is placed on examining these issues.

\section{Materials and Methods}

The research was implemented for the needs of Kokonaovic's doctoral dissertation, amongst the principals of preschool institutions $(\mathrm{N}=57)$ in Central Croatia. The data collection was done with the following instruments: Questionnaire on self-assessment of the preschool institution (adopted from Antulić Majcen, S. and Pribela Hodak, S, 2017), which measures the satisfaction, opinions and views of the employees about the crucial areas of the preschool institution's work quality (institution's strategies, organisational leadership, institution's culture, spatial-material and technical working conditions, curriculum and education process, human resources, cooperation and monitoring and evaluation); Questionnaire for evaluating the relationships in preschool institutions (adopted from Vujičić andTambolaš, 2017), which comprises of 21 variables on three subscales (cooperation, autonomy and support); Scale of principals' self-assessment of professional competences (adopted from Staničić, 2001), which entails 40 variables on 5 subscales (personal, developmental, professional, action and interpersonal or social competence).

The goal of the research was to test the direct/indirect influence of interpersonal relationships within the preschool institution on its work quality and ascertain the influence of professional competence as the mediation variable. According to the set goal, the following hypothesis was set:

$\mathrm{H} 1$ : It is assumed that interpersonal relationships in the preschool institution influence its work quality by means of professional competence.

\section{Results}

The hypothesis was tested via SEM (AMOS), whereby direct and indirect influences were examined. It is a recursive measurement model with two indicators: F1 (three composite variables) and F2 (eight composite variables). Before testing the mediation, the direct influence of the relationship (F1) on the institution's work quality (F2) was tested. The results are presented in Figure 1. 


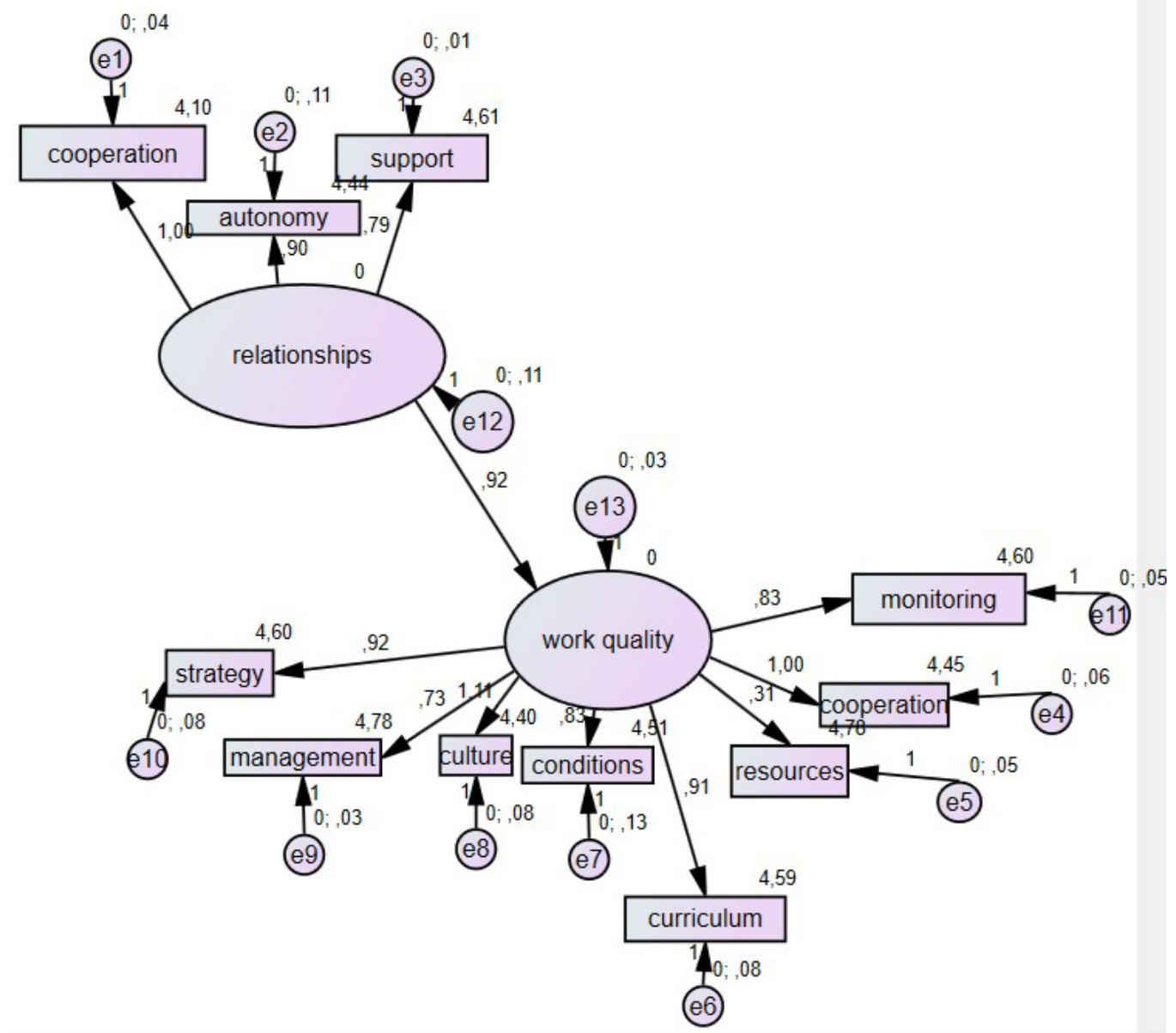

Figure 1. The model of direct influence

The path diagram (Figure 1) presents the unstandardised regression coefficients (betas). The contribution of relationships to work quality is statistically significant $(\beta=0,920)$. As assumed, positive interpersonal relationships directly affect the development of the institution's work quality. Table 1 displays the descriptive values of the regression weights.

Table 1

Regression Weights: (Group number 1 - Default model)

\begin{tabular}{|c|c|c|c|c|c|c|c|}
\hline & & & Estimate & S.E. & C.R. & $\mathrm{P}$ & Label \\
\hline $\mathrm{F} 2$ & $<-$ & $\mathrm{F} 1$ & 920 &, 145 & 6,321 & $\star \star \star \star$ & par_10 \\
\hline cooperationRAV_1 & $<-$ & F1 & 1,000 & & & & \\
\hline autonomyRAV_1 & $<-$ & F1 & 897 & 163 & 5,505 & $\star \star \star$ & par_1 \\
\hline supportRAV_1 & $<-$ & $\mathrm{F} 1$ &, 791 &, 089 & 8,877 & $\star \star \star$ & par_2 \\
\hline cooperation_1 & $<-$ & $\mathrm{F} 2$ & 1,000 & & & & \\
\hline resources_1 & $<-$ & $\mathrm{F} 2$ &, 314 &, 099 & 3,188 & 001 & par_3 \\
\hline curriculum_1 & $<-$ & $\mathrm{F} 2$ & 913 & 146 & 6,235 & $\star \star \star$ & par_4 \\
\hline conditions_1 & $<-$ & $\mathrm{F} 2$ & 829 & 170 & 4,863 & $\star \star \star \star$ & par_5 \\
\hline culture_1 & $<-$ & $\mathrm{F} 2$ & 1,107 &, 163 & 6,793 & $\star \star \star$ & par_6 \\
\hline management_1 & $<-$ & $\mathrm{F} 2$ &, 732 & 103 & 7,100 & $\star \star \star$ & par_7 \\
\hline strategy_1 & $<-$ & $\mathrm{F} 2$ & 919 & ,152 & 6,032 & $\star \star \star$ & par_8 \\
\hline monitoring_1 & $<-$ & $\mathrm{F} 2$ & 831 &, 128 & 6,497 & $\star \star \star$ & par_9 \\
\hline
\end{tabular}


In accordance with the values from Table 1, the direct influence of relationships on work quality is visible $(\beta=0,920)$. In line with the sign of the regression coefficient, it is concluded that the positive perception of interpersonal relationships leads to the increase of the work quality of a preschool institution. Furthermore, Table 2 presents descriptive values of the standardised regression weights.

Table 2

Standardized Regression Weights: (Group number 1 - Default model)

\begin{tabular}{llll}
\hline & & & Estimate \\
\hline F2 & $<--$ & F1 &, 875 \\
cooperationRAV_1 & $<--$ & F1 &, 857 \\
autonomyRAV_1 & $<--$ & F1 &, 660 \\
suupportRAV_1 & $<--$ & F1 &, 922 \\
cooperation_1 & $<--$ & F2 &, 808 \\
resources_1 & $<--$ & F2 &, 424 \\
curriculum_1 & $<--$ & F2 &, 751 \\
conditions_1 & $<--$ & F2 &, 616 \\
culture_1 & $<--$ & F2 &, 800 \\
management_1 & $<--$ & F2 &, 826 \\
strategy_1 & $<--$ & F2 &, 732 \\
monitoring_1 & $<--$ & F2 &, 774 \\
\hline
\end{tabular}

In order to examine the mediation role, the mediation latent variable professional competences is introduced into the model (Figure 2).

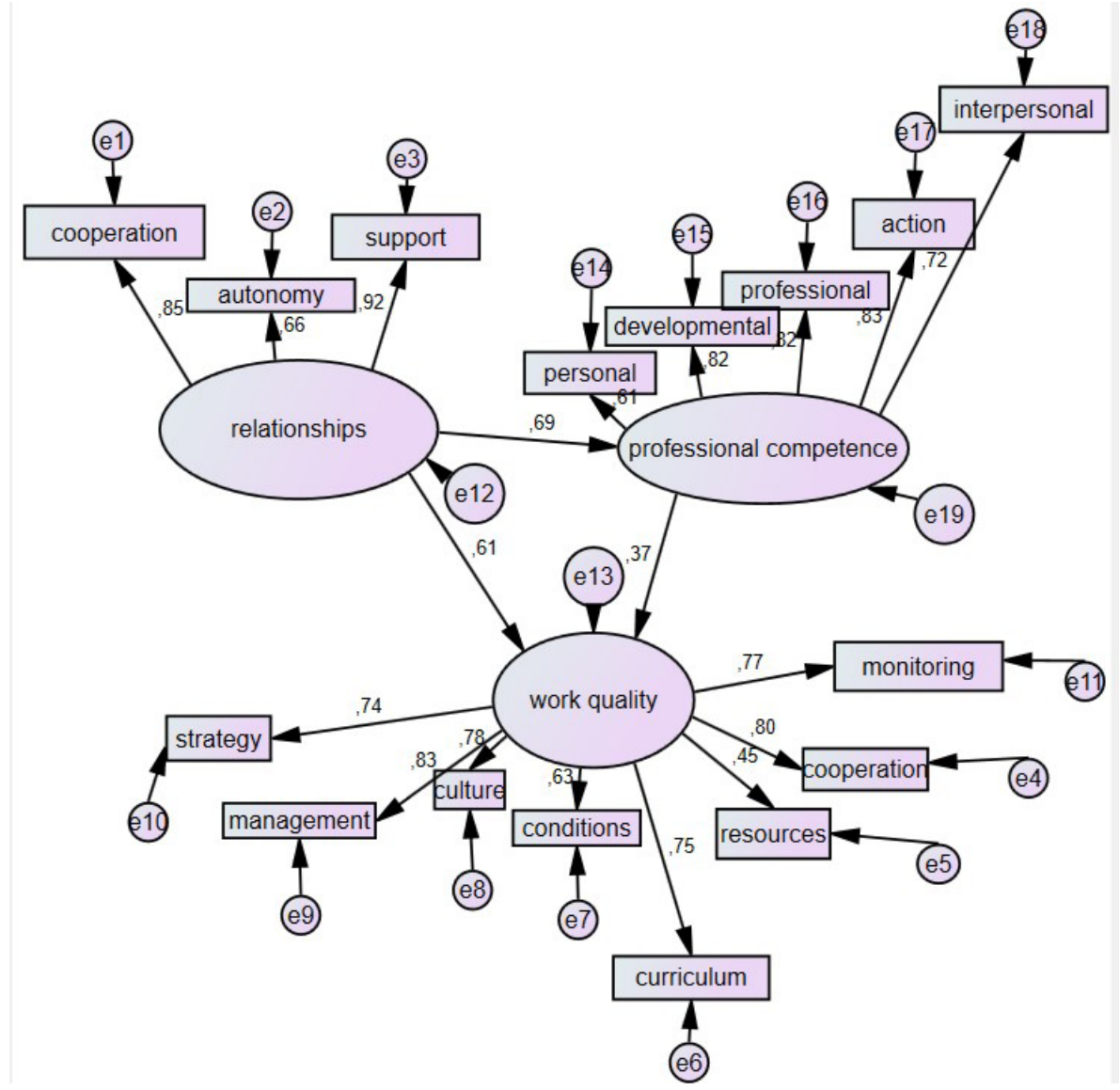

Figure 2. The model of mediation; indirect influence-standardised regression coefficients 
Figure 2 presents the mediation model. The values of indirect influence $(\beta=0,269)$ indicate the mediation role, i.e. positive interpersonal relationships via the principal's professional competence lead to positive perception of the preschool institution's work quality (Table 3).

Table 3

Standardized Indirect Effects (Group number 1 - Default model) Indirect Effects (Group number 1 - Default model)

\begin{tabular}{lrrr}
\hline & F1 & F3 & F2 \\
\hline F3 &, 000 &, 000 &, 000 \\
F2 &, 269 &, 000 &, 000 \\
interpersonal_1 &, 588 &, 000 &, 000 \\
action_1 &, 615 &, 000 &, 000 \\
professional_1 &, 568 &, 000 &, 000 \\
developmental_1 &, 723 &, 000 &, 000 \\
personal_1 &, 382 &, 000 &, 000 \\
monitoring_1 &, 764 &, 590 &, 000 \\
strategy_1 &, 853 &, 659 &, 000 \\
management_1 &, 681 &, 526 &, 000 \\
culture_1 &, 999 &, 771 &, 000 \\
condition_1 &, 777 &, 600 &, 000 \\
curriculum_1 &, 841 &, 649 &, 000 \\
resources_1 &, 308 &, 238 &, 000 \\
cooperation_1 &, 913 &, 705 &, 000 \\
\hline
\end{tabular}

Further, the statistical significance of the indirect influence $(p=0,016)$ is visible in Table 4 , which means this testing confirmed partial mediation.

For determining the statistical significance of the mediation effects, the bootstrapping method was used: Two Tailed Significance (BC), showing the indirect influence of interpersonal relationships on the work quality via the mediator of professional competence, which is statistically significant. 
Table 4

Indirect Effects - Two Tailed Significance (BC) (Group number 1 - Default model)

\begin{tabular}{llll}
\hline & F1 & F3 & F2 \\
\hline F3 & $\ldots$ & $\ldots$ & $\ldots$ \\
F2 &, 016 & $\ldots$ & $\ldots$ \\
interpersonal_1 &, 016 & $\ldots$ & $\ldots$ \\
action_1 &, 012 & $\ldots$ & $\ldots$ \\
professional_1 &, 011 & $\ldots$ & $\ldots$ \\
developmental_1 &, 014 & $\ldots$ & $\ldots$ \\
personal_1 &, 016 & $\ldots$ & $\ldots$ \\
monitoring_1 &, 012 &, 027 & $\ldots$ \\
strategy_1 &, 012 &, 024 & $\ldots$ \\
management_1 &, 018 &, 024 & $\ldots$ \\
culture_1 &, 018 &, 028 & $\ldots$ \\
conditions_1 &, 007 &, 017 & $\ldots$ \\
curriculum_1 &, 008 &, 032 & $\ldots$ \\
resources_1 &, 015 &, 035 & $\ldots$ \\
cooperation_1 &, 007 &, 035 & $\ldots$ \\
supportRAV_1 & $\ldots$ & $\ldots$ & $\ldots$ \\
autonomyRAV_1 & $\ldots$ & $\ldots$ & $\ldots$ \\
cooperationRAV_1 & $\ldots$ & $\ldots$ & $\ldots$ \\
\hline
\end{tabular}

After introducing the mediation variable Professional competence, the influence of exogenous variable relationships on endogenous variable work quality was decreased; however, it did not disappear by means of the mediator, but was still statistically significant. The fitness of the model via incremental and parsimony fit indices was not confirmed, although the absolute fit index was at a liminal value (RMSEA $=0,10)$ above which the model is not considered appropriate

Kokanović (2021) established in her work that principals who are deemed professionally competent positively affect the work quality of the preschool institution via their behaviour and relationships within the institution. In this research, the direct influence was examined of the relationships in the preschool institution on the quality of its work, and it was proven as statistically significant. Furthermore, partial mediation was confirmed by introducing professional competence as the mediation variable. Positive interpersonal relationships lead to positive perception of professional competence, whereby contributing to greater work quality of the preschool institution. The principals who strive for a learning community and promote and advocate open and appreciative communication amongst all participants greatly contribute not only to their own but also to professional development of all relevant actors. Preschool institutions that base their practice on quality, reflexive dialogues and discussion indisputably effect positive development of its quality. This confirms the set hypothesis that relationships, via professional competences of the principal, positively affect the work quality of preschool institutions.

\section{Discussion}

The hypothesis of this research referred to the possible mediating role of the professional competence of the principal in the relationship between interpersonal relationships and the quality of work of the preschool institution. The analysis used a bootstrapping method (2000 replicate samples) with a 
$95 \%$ confidence interval. The results showed that there is a significant indirect impact of interpersonal relationships on the quality of work of the institution through professional competence $(\beta=0,269)$. This is a partial mediation, because the direct impact of interpersonal relationships on the quality of work after the introduction of professional competence, as a mediator variable, still remains significant $(p=0,016)$. Thus, it can be said that interpersonal relationships are positively related to the quality of work of the preschool institution and that this relationship is partly mediated by the professional competence of the principal. Thus, we confirmed the thesis of the author Slunjski (2018) who believes that the role of a competent director is to encourage and develop interpersonal relationships and staff expertise, which will lead to positive development of the quality of the institution, while incompetent director will passively observe and expect its development. Accordingly, it can be concluded that in preschool institutions in which quality interpersonal relationships are developed, they lead to a more positive perception of the professional competence of the principal, which leads to the development of the quality of work of the institution. Strong interpersonal relationships, which lead to the positive development of the institution, will remain effective even after the director leaves office. A professionally aware principal who shows care and support for strengthening such relationships sees the institution as a testing ground for joint growth and development, creating conditions and opportunities for joint learning and capacity building of employees and then the institution. Accordingly, it can be concluded that in preschool institutions where quality interpersonal relationships are developed, they lead to a more positive perception of the professional competence of the principal, which leads to the development of the quality of the institution's work. The limitation of the research is a relatively small number of participant principals $(N=57)$, and the implementation of exclusively quantitative approach in researching the stated constructs. Since the study was done during June and July 2020, for the purposes of writing a doctoral dissertation by Kokanović (2021), after a several months long cease of regular preschool institutions' work due to the global pandemic caused by the COVID-19 virus, the small number of the filled-out questionnaires was not surprising, but it was still satisfactory for further analysis. Taking into consideration the complexity and specificity of the functioning of preschool institutions, future research would advisedly implement the qualitative approach in order to attain a more in-depth understanding of this multifaceted issue. The space for researching these areas exists, and it is desirable to obtain scientific insight in that direction in order to enrich the literature in the field of early and preschool education and indicate the significance of the professionalization of the principal's role.

\section{Conclusion}

Nowadays it is expected of the principals to develop and promote the vision, plans, politics and action in cooperation with employees, parents and children/students in order to more efficiently and successfully head the preschool institution. To do all this in a quality manner, the function of the principal needs to become a profession, i.e. acquiring professional competence through continuous programmes of education should be provided. Without the planned and systematic pursuit in this meaningful filed on the level of a national educational policy, the management of preschool institutions boils down to individual perception of the professional work of each principal within preschool institutions. Analysis of the research on this topic in the field of educational management and early and preschool education has not found similar studies, so the results of the present paper can contribute to understanding the complexity of the principal's role, therein its professionalization. The content and results of this research indicate the significance of investing in this part of the education system on the part of educational policy's creators, emphasising the implementation of already existing competence standards (Staničić, Kovač and Đaković, 2016) in order to regulate the function of the principal into a profession. To realise the full potential of the preschool institution and its stakeholders, it is necessary to define the qualifications and competences the principals should possess before assuming this role, and then also provide continuous evaluation of his/her work's accomplishment and the acquired competences. Professionalization of the principals would guarantee professionally competent, educated and aware experts managing education institutions, thereby positioning national education policy on a higher level since Croatia is at the back of the list of European countries when it comes to prescribing the standards for this important role in the education system. To become and remain the principal of an education institution based on national standards will empower the development of professional learning communities, thereby ensuring developmental quality worthy of our society's most important members: children. 


\section{Acknowledgements}

The paper Professionalization of the principal's role is based on the gathered data in the research implemented for the needs of a doctoral dissertation by Kokanović, T. (2021). The dissertation was defended on 2 March 2021 under the mentorship of prof.dr.sc. Siniša Opić. Thank you to all the respondents, who participated in completing the surveys and thus contributed to the development of this paper.

\section{Conflict of interests}

The authors declare no conflict of interest.

\section{References}

Antulić Majcen, S., \& Pribela Hodap, S. (2017). Prvi koraci na putu prema kvaliteti [First steps on the path to quality]. Samovrednovanje ustanova ranog i predškolskog odgoja i obrazovanja. Zagreb: Nacionalni centar za vanjsko vrednovanje obrazovanja. Retrieved from: https://www.bib.irb.hr/915027?rad=915027

Caldwell, B.J. (2005). School-Based Management. Brussels/Paris, The International Academy of Education/UNESCO, The International Institutte for Educational Planning, Education Policy Series, 3.

Dahlberg, G., \& Moss, P. (2006). Etchic and Politics in Early Childhood Education. London: Routledge Falmer.

Earley, P., \& Greany, T. (2017). School Leadership and Eeducation System Reform. Bloomsbury Publishing. https://doi.org/10 .1080/02680939.2019.1696037

Europska komisija (2014). Proposal for key principles of a Quality Framework for Early Childhood Education and Care. Izvješće Radne skupine za rani i predškolski odgoj i obrazovanje pod pokroviteljstvom Europske komisije. Retrieved from: http:// ec.europa.eu/assets/eac/education/policy/strategicframework/archive/documents/ececquality-framework_en.pdf (13.1.2019.)

European Council (2009). Council conclusions of 26 November 2009 on the professional development of teachers and school leaders. Official Journal of the European Union. Retrieved from: http://eurlex.europa.eu/LexUriServ/LexUriServ.do?uri =OJ:C:2009:302:0006:0009:EN:PDF. (24.09.2018.)

ETUCE (2008). Teacher education in Europe, Brussels: European trade union committee for education and Comitee syndical europeen de l'education/online/. Retrieved from: http://etuce.homestead.com/Publications2008/ETUCE_PolicyPaper_ en_web.pdf (24.09.2019.)

Fullan, M. (1993). Change Forces. London: The Falmer Pres.

Fullan, M. (2011). The Moral Imperative Realized. Thousand Oaks, CA: Corwin Press. https://doi.org/10.1177/136548021101 40021002

Gopnik, A., Meltzoff, A. N., Kuhl, P. K., \& Jagodić, G. K. (2003). Znanstvenik u kolijevici: što nam rano učenje kazuje o umu. [The scientist in the cradle: what early learning tells us about the mind] Educa.

Grint, K., \& Holt, C. (2011). Leading questions: If 'Total Place','Big Society'and local leadership are the answers: What's the question?. Leadership, 7(1), 85-98. https://doi.org/10.1177/1742715010393208

Hersey, P., Blanchard, K., \& Johnson, D. (2008). Management of Organizational Behavior: Leading Human Resources, $9^{\text {th }}$ edn. Upper Saddle River, NJ: Pearson Education.

Jurčević-Lozančić, A. (2011). Teorijski pogledi na razvoj socijalne kompetencije predškolskog djeteta [Theoretical views on the development of social competence of a preschool child]. Pedagogijska istraživanja, 8(2), 271-279. Retrieved from https://hrcak.srce.hr/116661

Kokanović, T. (2021). Profesionalne kompetencije ravnatelja u razvoju kvalitete rada predškolskih ustanova [Professional competencies of principal in the development of quality of preschool institutions]. Doktorska disertacija. Zagreb: Filozofski fakultet Sveučilišta u Zagrebu. Retrieved from https://repozitorii.ffzg.unizg.hr/islandora/object/ffzg:4025

Leithwood, K., \& Day, C. (2007). Successful Principal Leadership in Times of Change. Dordrecht, Netherlands: Springer.

Matsumura, L. C., Garnier, H. E., \& Resnick, L. B. (2010). Implementing literacy coaching: The role of school social resources. Educational Evaluation and Policy Analysis, 32(2), 249-272. https://doi.org/10.3102/0162373710363743

Melhuish, E., Ereky-Stevens, K., Petrogiannis, K., Ariescu, A., Penderi, E., Rentzou, K. \& Broekhuisen, M. (2015). A review of research on the effects of early childhood education and care (ECEC) on child development. CARE project; Curriculum Quality Analysis and Impact Review of European Early Childhood Education and Care (ECEC). https://doi. org/10.4324/9780203967676

Miljak, A. (2009). Življenje djece u vrtiću [Children's life in kindergarten]. Zagreb: SM naklada..

Mlinarević, V. (2004). Vrtićko okruženje usmjereno na dijete [Child-centered kindergarten environment]. Život i škola, 11(1), 112-119. Retrieved from https://bib.irb.hr/datoteka/183458.Vrtino_okruzenje_usmjereno_na_dijete.pdf

OECD (2005). Teachers Matter (Hungarian version): Attracting, Developing and Retaining Effective Teachers (Summary), OECD Publishing, Paris, https://doi.org/10.1787/9789264018044-sum-hu.

Peterson, K. (2002). Positive or Negative? Journal of Staff Development, 23(3), 5-10.

Rinaldi, C. (2006). In dialogue with Reggio Emilia: Listening, researching and learning. Psychology Press. https://doi. org/10.4324/9780203317730

Rood, J. (2006). Leadership in Early Chilhood: The Pathway to Professionalism. Buckingham: Open University Press.

Rood, J. (2013). Leadership in Early Childhood: The Pathway to Professionalism. London: Routledge.

Sekulić-Majurec, A. (1997). Integracija kao pretpostavka uspješnije socijalizacije djece i mladeži s teškoćama u razvoju: očekivanja, postignuća, perspektive [Integration as a pre-requisite for more successful socialization of children and youth with developmental difficulties: expectations, achievements, perspectives]. Društvena istraživanja, 6(30+31), 537-550. Retrieved from https://hrcak.srce.hr/31662 
Slunjski, E. (2006). Stvaranje predškolskog kurikuluma u vrtiću-organizaciji koja uči [Creating a pre-school curriculum in a kindergarten-learning organization]. Zagreb/Čakovec: Mali profesor/Visoka učiteljska škola. Retrieved from https:// www.bib.irb.hr/360924?rad=360924

Slunjski, E. (2008). Dječji vrtić-zajednica koja uči, mjesto dijaloga, suradnje i zajedničkog učenja. [Kindergarten-learning community, a place of dialogue, cooperation and joint learning]. Zagreb: Spektar Media.

Slunjski, E. (2011). Različiti pristupi istraživanju i tvorbi kurikuluma [Different approaches to research and curriculum development]. U: Maleš, D. (ur), Nove paradigme ranoga odgoja [New paradigms of early childhood education]. Zagreb: Filozofski fakultet Sveučilišta u Zagrebu Zavod za pedagogiju, str.179-208.

Slunjski, E. (2018). Izvan okvira 3, Vođenje:prema kulturi promjene. [Outside the Box 3, Leadership: towards a culture of change]. Zagreb: Element.

Snyder, P.A., Denney, M.K., Pasia, C., Rakap, S. i Crowe, C. (2011). Professional development in early childhood intervention: Emerging issues and promising approaches. In Groark, C. and Kaczmarek, L.A. (Eds), Early childhood intervention: Shaping the future for children with special needs and their families, (Vol. 1-3). Santa Barbara, CA: Praeger/ABC-CLIO. Pp. 169-204.

Staničić, S. (2001). Kompetencijski profil ravnatelja [Competence profile of the principal]. U: Staničić, S. (ur.) Školski priručnik 2001./2002. Zagreb: Znamen, str.179-185

Staničić, S. (2006). Menadžment u obrazovanju [Management in education]. Rijeka: Vlastita naklada.

Staničić, S., Kovač, V., Đaković, O. (2016). Standardi za ravnatelje odgojno-obrazovnih ustanova (Izvješće o ostvarenju 1. i 2. zadaće Ekspertne radne skupine za provedbu 5. cilja Strategije obrazovanja, znanosti i tehnologije - ERS-e5) [Standards for principal"s of educational institutions (Report on the realization of tasks 1 and 2 of the Expert Working Group for the implementation of Objective 5 of the Strategy of Education, Science and Technology - ERS-e5)]. Zagreb: Nacionalni centar za vanjsko vrednovanje obrazovanja. https://doi.org/10.21861/hgg.2011.73.01.18

Strategija obrazovanja znanosti i tehnologije [Science and Technology Education Strategy]. (2014). Narodne novine, br. 124/2014. Retrieved from https://mzo.gov.hr/UserDocsImages/dokumenti/Obrazovanje/Strategija\%20 obrazovanja,\%20znanosti\%20i\%20tehnologije.pdf

Vandenbroeck, M. et al. (2017). Benefits of early childhood education and care and the conditions for obtaining them, Izvješce Europske stručne skupine za ekonomiju obrazovanja. Retrieved from: http://www.eenee.de/eeneeHome/EENEE/ Analytical-Reports.html (12.1.2019.)

Vujičić, L. (2011). Istraživanje kulture odgojno-obrazovne ustanove [Research of the culture of an educational institution]. Zagreb: Mali profesor. Retrieved from: https://www.bib.irb.hr/530858?rad=530858

Vujičić, L., \& Tambolaš, A. Č. (2017). Profesionalni razvoj odgajatelja- izazov za pedagoga [The professional development of educators - a challenge for pedagogues]. U: Turk, M. (ur.), Suvremeni izazovi u radu (školskog) pedagoga - Zbornik u čast Stjepana Staničića, Rijeka: Filozofski fakultet Rijeka, str.132-156. https://doi.org/10.19090/zop.2017.26.7-29 
